\title{
Czas codzienny i czas odświętny - ich przenikanie w stylach życia współczesnej młodzieży
}

\section{KEY WORDS}

everyday time, festive time, youth, lifestyle, modernity

\section{ABSTRACT}

Peret-Drążewska Paulina, Peret Justyna, Czas codzienny i czas odświętny - ich przenikanie $w$ stylach życia współczesnej młodzieży [Time Everyday and Festive Time and Their Penetration in the Lifestyles of Modern Youth]. Kultura - Społeczeństwo - Edukacja nr 2(10) 2016 , Poznań 2016, pp. 249-258, Adam Mickiewicz University Press. ISSN 2300-0422. DOI 10.14746/kse.2016.10.19.

Contemporary socio-cultural situation based on globalization make that many categories, concepts and theories required decontextualization, then recontextualization and redefinition. This process also applies to so intuitively obvious category, which is time. The specificity of the "survival" of time, perception and understanding have changed significantly influenced by current trends of modern times, such as the primacy of pleasure, the cult of success, mainstream consumerism, mass media influence. Because of these issues important and necessary it seems that re-thinking on modern understanding of time as a sociocultural category, which characterizes the quality and style of life of individuals as it exists in the current, post-modern space-time.

This article provides theoretical considerations on the nature and specificity of everyday time and festive time in the context of current sociocultural based globalization processes. Assuming that the time and its fulfillment, or lifestyle are subject to the relationship of interdependence, the analysis will undergo a proposition about the consistency / heterogeneity of the individual's life style presented in the context of the division of temporal existence of the unit on time everyday and festive time. Considerations will address today's youth. It results from the specific lifestyle of this age group, which is due to the peculiarities of the development phase and the "soak" contemporary trends, in particular understands everyday / celebrating. 


\section{Wprowadzenie}

Aktualna rzeczywistość społeczno-kulturowa jawi się jako szereg postępujących zmian opartych na zasadzie odwrotu od rutyny, pewności i trwałości, co nie pozostaje bez znaczenia dla egzystencji jednostki partycypującej w realiach pełnych sprzeczności. Należy mieć zatem na uwadze fakt, iż rys funkcjonowania społeczno-kulturowego jednostki we współczesnym świecie wyznaczony jest przez ciąg nieskończonych zmian generowanych przez trendy ponowoczesności. Współczesne warunki społeczno-kulturowe, wynikające ze zjawiska globalizacji, sprawiają również, iż wiele kategorii, pojęć i teorii uległo dekontekstualizacji, następnie rekonteksualizacji i redefinicji. Te procesy dotyczą także tak intuicyjnie oczywistej kategorii, jaką jest czas.

Specyfika „przeżywania” czasu, jego postrzeganie oraz rozumienie uległy istotnym zmianom wynikającym $\mathrm{z}$ trendów współczesności, takich jak prymat przyjemności, kult sukcesu, nurt konsumpcjonizmu, wpływ mass mediów. W tym kontekście istotny i konieczny wydaje się ponowny namysł nad współczesnym rozumieniem czasu, który jako kategoria społeczno-kulturowa nie jest bez znaczenia dla jakości i stylu życia jednostek egzystujących w aktualnej, ponowoczesnej czasoprzestrzeni.

$\mathrm{W}$ kontekście podjętych $\mathrm{w}$ artykule rozważań istotne wydają się powiązania pomiędzy czasem jako kategorią autoteliczną a jego wypełnieniem, czyli stylem życia, bowiem, jak tłumaczy Elżbieta Tarkowska: „stosunek do czasu informuje o charakterze danej kultury, etosu czy stylu życia i o swoistych cechach tych całości. Koncepcje czasu i nastawienia wobec czasu pozwalają dotrzeć do pewnych bardziej złożonych zjawisk, do trudniej dostępnych struktur” (Tarkowska, 1992: 32).

Niniejszy artykuł zawiera rozważania teoretyczne nad istotą oraz specyfiką „Czasu codziennego” oraz „czasu odświętnego” "w kontekście aktualnych warunków społeczno-kulturowych opartych na procesach globalizacyjnych. Wychodząc z założenia, iż czas oraz jego wypełnienie, czyli styl życia, podlegają relacji współzależności, analizie poddana zostanie teza o spójności/niejednorodności prezentowanego stylu życia jednostki w kontekście podziału temporalnego egzystencji jednostki na czas codzienny i czas odświętny. Rozważania dotyczyć będą głównie współczesnej młodzieży. Specyfika stylu życia niniejszej grupy wiekowej, która ze względu na osobliwości etapu rozwojowego oraz „przesiąkniecie” trendami współczesności sprawia, iż w sposób szczególny rozumie ona codzienność/odświętność.

\footnotetext{
${ }^{1}$ Kategorie „czas codzienny” oraz „czas odświętny” stanowią przedmiot analiz socjologicznych, są terminami zdefiniowanymi w literaturze przedmiotu, m.in. w: Bogunia-Borowska, 2009; Sztompka, Bogunia-Borowska, 2008; Sulima, 2000.
} 


\section{Czas codzienny a czas odświętny}

Kategoria codzienności jest pojęciem odnoszącym się bezpośrednio do terminu „czas”, bowiem mówiąc o codzienności, mamy na myśli jakość przeżywanego czasu, jego wypełnienie rutynowymi, codziennymi czynnościami i obowiązkami. Zatem czas jest przestrzenią do wypełnienia, podłożem wszelkich działań i aktywności, które zależne są od specyfiki owego czasu. Każda sytuacja jest określona w danej czasoprzestrzeni, więc postrzeganie rzeczywistości i jej eksploracja wynika $\mathrm{z}$ dużej mierze $\mathrm{z}$ jakości doświadczania czasu oraz przyjętych orientacji temporalnych.

Niniejsza wstępna teza prowadzi do stwierdzenia, iż styl życia jednostki należy rozpatrywać między innymi przez pryzmat specyfiki czasu, w nawiązaniu do którego ów styl życia jest analizowany. Nawet podstawowa definicja czasu w ujęciu antropologicznym, wskazuje na zależność stosunku do świata (wyznaczającego styl życia) od danego czasu. W owej definicji czas to „miernik trwania, jest $\mathrm{w}$ antropologii jedną z kluczowych wartości tożsamości kulturowej, kształtujących życie jednostki i zbiorowości, do której ta przynależy, oraz ich stosunek do świata" ${ }^{2}$. Mając na uwadze powyższą refleksję, dalsza część narracji dotyczyć będzie istoty i specyfiki czasu codziennego oraz odświętnego.

Ze względu na permanentną wszechobecność czasu naukowe interdyscyplinarne rozważania nad niniejszą kategorią podejmowane są $\mathrm{z}$ różnych perspektyw i punktów widzenia, zatem, co oczywiste, analizy te ulegają fragmentaryzacji i specyfikacji. Tak oto mówimy o czasie w perspektywie temporalnej (przeszłość, teraźniejszość, przyszłość), w nawiązaniu do obowiązków (czas wolny i czas pracy), a także do częstotliwości i przygotowań do życiowych aktywności. W tym wymiarze mówi się o czasie codziennym, którego nie sposób analizować bez jego aspektu kontrastowego, czyli czasu odświętnego. Podkreśliła to Elżbieta Tarkowska, wyjaśniając istotę codzienności/odświętności oraz ich wzajemnych zależności. Autorka zaznacza, iż:

to, co codzienne, utożsamiane jest $\mathrm{z}$ tym, co zwykłe, powszechne, powtarzalne, rutynowe, typowe, zwyczajowo przyjęte, normalne, a więc swojskie i oczywiste. Owo „codzienne” przeciwstawiane bywa takim cechom, jak: odświętne, wyjątkowe, niezwykłe, przypadkowe, rzadkie, inne, obce. W tych charakterystykach uwzględnione są już wybrane elementy temporalne, odnoszące się w jakiś sposób do zjawisk czasu, a mianowicie powtarzalność,

\footnotetext{
${ }^{2}$ https://pl.wikipedia.org/wiki/Czas_\%28antropologia\%29, dostęp: 18.12.2015. Wybór źródła definicji pojęcia czas (wolna encyklopedia internetowa Wikipedia) nie był przypadkowy, wynikał bowiem z faktu, iż jest to jedna z najczęściej odwiedzanych witryn internetowych w Polsce (liczba użytkowników strony na miesiąc przekracza $10 \mathrm{mln}$ ). Powołanie się na niniejsze źródło wiedzy miało na celu ukazanie powszechności rozumienia terminu czas poprzez pryzmat powiązań czasu ze stylem życia. https://pl.wikipedia.org/wiki/Polskoj\%C4\%99zyczna_Wikipedia\#cite_note-1, dostęp: 21.01.2016.
} 
rutyna, trwałość, zwyczaj. Wsparte mocno na przeszłości, określenia te odsyłają do trwającej ciągle teraźniejszości. Trwałość codzienności, to trwałość i powtarzalność teraźniejszości; jakkolwiek mocno oparte na przeszłości, życie codzienne jest domeną teraźniejszości. (Tarkowska, 1992: 68-69)

Intuicyjnie i potocznie nie jest trudno określić specyfikę czasu codziennego. Wychodząc z tego założenia, część badaczy codzienności nie widzi konieczności ustalania jej ram definicyjnych. Na przykład Roch Sulima pisze, iż codzienność „jest nieuchronna jak pogoda i nie wymaga definiowania, bez wątpienia jest nieustannie praktykowana, stanowiąc najbardziej oczywistą, obecną w bezpośrednim doświadczeniu, najbardziej realną i dostępną ludzkiej percepcji formę bytu" (Sulima, 2000: 7). Z kolei Jerzy Jastrzębski zaznacza, że „codzienności” z reguły się nie definiuje, chociaż można o niej "deliberować i fantazjować nieskończenie” (Jastrzębski, 2003: 12).

Warto w tym miejscu przedstawić cechy życia codziennego w ujęciu Piotra Sztompki, który wyróżnił je na podstawie szerokich analiz terminologicznych. Tak oto autor pisze, że

życie codzienne to zawsze życie z innymi i w obecności innych, a zatem codzienność dzieje się, rozgrywa się zawsze w towarzystwie innych; życie codzienne to splot zdarzeń, które nieustannie się powtarzają (cyklicznie, rytmicznie, rutynowo - dzień w dzień, tydzień $\mathrm{w}$ tydzień, miesiąc $\mathrm{w}$ miesiąc, rok w rok); życie codzienne przybiera najczęściej formy rytualne, które są wykonywane zgodnie $\mathrm{z}$ wpojonym i bezrefleksyjnie realizowanym scenariuszem zdominowanym przez nawyki; życie codzienne posługuje się naszą cielesnością, angażując wszystkie nasze emocje; życie codzienne zawsze ulokowane jest w określonej przestrzeni, toczy się w różnych miejscach - w szkole, w domu, na ulicy - co w konsekwencji determinuje jego treść i charakter; epizody życia codziennego zwykle mają określoną trwałość, wytyczone ramy czasowe - krótsze lub dłuższe i z tego względu wszystkie niosą rozmaite konsekwencje; życie codzienne zwykle ma charakter bezrefleksyjny, niemalże automatyczny; a ponadto cechuje się spontanicznością. (Sztompka, 2008: 24-30)

Dopełniającym kontekstem refleksji o codzienności jest odświętność lub też inaczej niecodzienność, która stanowi czas odejścia od przedstawionych powyżej zasad składających się w całość, zwaną codziennością. Odświętność jest więc przerwaniem codzienności, zatem zdarza się rzadziej, charakteryzuje się większym stopniem refleksyjności oraz wymaga większej ilości poczynionych przygotowań.

Z pozoru antagonistyczna relacja czas codzienny - czas odświętny traci na znaczeniu w obliczu współczesnych warunków społeczno-kulturowych, ponieważ aktualne trendy ponowoczesności sprawiają, iż codzienność i odświętność przeplatają się wzajemnie, tworząc unikalną celebrację czasu codziennego oraz 
sprowadzenie czasu odświętnego do wymiaru codzienności. W tym kontekście warto przywołać tezę Sławomira Krzychały, który pisze, iż „codzienność jest doświadczana jako oczywistość i jako zagadka, jako zastany rytm i jako zadanie innowacji, jako całościowe doświadczenie i jako fragmentaryczne obszary aktywności, jako zindywidualizowane strategie i jako zbiorowe praktyki" (Krzychała, 2007: 35). Niniejsza sytuacja znamionuje zmiany w postrzeganiu kategorii czasu, a co za tym idzie jakości preferowanego stylu życia jednostek ponowoczesności.

Podejmując rozważania nad pojęciem czasu, należy podkreślić jego wielokontekstowość i multiplikację znaczeń. Ze względu na podjęte w artykule zagadnienia uwypuklony zostanie w szczególności kulturowy aspekt czasu, bowiem, jak zaznaczył Wojciech Muszyński,

czas jest pojęciem filozoficznym, ma swoje znaczenie fizyczne, ale również jest kategorią kulturową. We współczesnym społeczeństwie czas analizowany jest także jako dobro konsumpcyjne. W tych kontekstach można wskazywać, że społeczności ludzkie różnią się sposobami podejścia do czasu, jego wykorzystaniem, a także formami zagospodarowania. (Muszyński, 2009: 7)

Zatem czas jest nieodzownie związany ze specyfiką aktualnych warunków społeczno-kulturowych, co zostanie szczegółowo dookreślone w dalszej części narracji.

\section{Specyfika współczesności w kontekście rozróżnienia czasu na codzienny i odświętny}

Ponowoczesna rzeczywistość społeczno-kulturowa zrywa z kanonem zastanych prawd i oczywistości, wymagając ciągłej rekonstrukcji i ponownych analiz podejmowanych w świetle aktualnej obserwacji dynamicznie zmieniającej się wzajemnej relacji na linii jednostka a jej środowisko życia. Przestrzeń życiowa człowieka oraz jego przeżywanie codzienności są wzajemnie zdeterminowane, co nie pozostaje bez znaczenia dla analiz preferowanych stylów życia, szczególnie w grupie adolescentów. Również czas jako kategoria społeczna nabrał innego znaczenia w obliczu obecnych warunków społeczno-kulturowych. Niniejszą zależność pomiędzy postrzeganiem czasu a jakością zaistniałych zmian dostrzec można w rozważaniach teoretycznych Agnieszki Cybal-Michalskiej, która podkreśla, iż: „na szczególną uwagę zasługuje wymiar czasu (nieprzewidywalność zmienność tempa zmian rzeczywistości społeczno-kulturowej) oraz wymiar przestrzeni (zróżnicowanie zakresu zmian, jakim podlegają różne społeczeństwa)" (Cybal-Michalska, 2013: 373). 
Żyjąc w kulturze natychmiastowości, kiedy to czas jest zarówno bardzo cenny, jak również nieistotny, jednostki skoncentrowane są na kontemplacji czasu teraźniejszego. Ponowoczesne postrzeganie czasu charakteryzuje się naciskiem na aktualne wydarzenia życiowe, bowiem jak zaznacza Daria Hejwosz-Gromkowska: „w świecie, w którym wszystko odbywa się coraz szybciej, nie pozostaje nic innego, jak utrzymać stan gotowości do podejmowania działań. Budowanie długookresowych strategii czy też programów wydaje się nie tyle pozbawione sensu, co mało skuteczne, bowiem kultura natychmiastowości nakazuje szybką reakcję" (Hejwosz-Gromkowska, 2014: 307). Nie bez znaczenia dla postrzegania czasu pozostaje współczesny trend kultury hedonizmu, mówiący o maksymalizacji doznań przyjemnych przy minimalizacji doznań przykrych, co również wpływa na zmianę gospodarki czasem.

Wracając do rozważań nad podziałem czasu na ten codzienny i odświętny, tym razem $\mathrm{w}$ kontekście przemian współczesnego świata, należy podkreślić wzajemne ich przenikanie, hybrydyzację czy nawet zatarcie granic (we współczesności dzieje się tak przecież z niemalże wszystkimi elementami życia społeczno-kulturowego). Zatem, dążąc do przyjemności, czynimy z czasu codziennego czas odświętny, pragniemy wręcz odwrotnie proporcjonalnego wymiaru czasu codziennego i odświętnego. Jednakże $\mathrm{z}$ drugiej strony jednostka ponowoczesności nie przykłada zbytniej uwagi do celebracji czasu odświętnego. Nie chcąc tracić czasu tylko i wyłącznie na codzienność, pragniemy, aby każdy dzień miał w sobie coś z codzienności i święta. Zdaniem Zygmunta Baumana „to właśnie wysokie prawdopodobieństwo zajść niecodziennych jest dziś doświadczeniem codziennym (...), niecodzienność jest dziś codziennością" (Bauman, 2009: 78).

Zatem nie należy postrzegać obu wymiarów czasu opozycyjnie. Tego zdania jest również Piotr Sztompka, który mówi, iż codzienność zawiera w sobie

zarówno pośpiesznie spożyty obiad w pracy, jak i uczestnictwo w niedzielnej mszy, zakupy w markecie, jak i złożenie wieńca pod pomnikiem, oglądany „na żywo” mecz piłkarski, jak i symfoniczny koncert. W konsekwencji, przywołane powyżej praktyki dnia codziennego $\mathrm{w}$ rozumieniu autora, stanowiąc równorzędne elementy życia codziennego człowieka pojawiające się z różną częstotliwością, zamykają w sobie zarówno Durkheimowską dziedzinę, profanum, jak i sacrum. (Sztompka, 2008: 24)

Nastawienie na hybrydyzację oraz indywidualizację życia współczesnego wybrzmiewa również w rozważaniach Zbyszko Melosika, który pisze, iż:

mozaikowatości i fragmentaryczności sfery popkultury i konsumpcji towarzyszą przy tym nieuchronne rozproszenie i niejednoznaczność tożsamości. Jest to więc rzeczywistość, w której „wszystko zdaje się być dozwolone”, panuje w niej możliwość swobodnego nadawania znaczeń oraz daleko idącej indywidualizacji życia i codzienności. (Melosik, 2013: 10) 
Jak wynika z niniejszych rozważań, nastawienie wobec czasu znamionuje kreację określonego stylu życia. Trafnie podkreślił ową zależność Sławomir Krzychała, który twierdzi, iż „zrozumienie i działanie nie stanowią w kontekście codzienności rozłącznych zbiorów. Zrozumienie jest formą działania i wynika z działania, działanie jest formą rozumienia i wynika ze zrozumienia" (Krzychała, 2007: 35). Stąd też dalsze refleksje dotyczyć będą działania, czyli jakości stylu życia współczesnej młodzieży, spójnego bądź rozbieżnego w kontekście nastawienia wobec codzienności i święta.

\section{Style życia współczesnej młodzieży}

Grupą społeczną szczególnie podatną na zmiany dokonujące się we współczesnym wymiarze życia społeczno-kulturowego jest niewątpliwie młodzież. Młode pokolenie, socjalizowane do egzystencji w zastanych warunkach ponowoczesności, znakomicie się do nich dostosowuje poprzez życie zgodne z trendami współczesności. Dlatego też styl życia młodzieży nasycony jest sztandarowymi elementami globalnej ekumeny kulturowej ${ }^{3}$, do których należą: konsumpcjonizm, popkultura, mediatyzacja, nowoczesne technologie informacyjne i komunikacyjne. Niniejsze trendy ponowoczesności w znaczącym stopniu kształtują styl życia adolescentów, będąc jednocześnie jego znaczącymi składowymi.

Młodzi ludzie mają świadomość specyfiki trendów ponowoczesności i na jej podstawie kreują swoją egzystencję. Potwierdzają to wyniki badań własnych realizowanych w 2013 roku na temat obrazu współczesnej młodzieży postrzeganego z perspektywy rówieśników, $\mathrm{w}$ ramach których jeden z problemów badawczych dotyczył opinii współczesnej młodzieży na temat orientacji współczesnego społeczeństwa. Grupa osób badanych (439 uczniów szkół średnich zlokalizowanych na terenie województwa wielkopolskiego) najczęściej podkreślała takie właściwości współczesności, jak: rozwój technik informacyjnych poszerzający zakres i możliwości kontaktu między ludźmi całego globu, kulturę popularną, z podkreśleniem kultury upozorowania, reality show, kultu ciała i seksualności, kulturę konsumpcji zgodną z hasłem "towary kupują swoich nabywców” (Peret-Drążewska, 2014: 207-208). Niniejsze orientacje współczesnego społeczeństwa to nieodzowne elementy codzienności współczesnej młodzieży, zatem owa grupa wiekowa stanowi istotny wyznacznik aktualnych trendów w kształtowaniu stylu życia.

Młodzież jako najbardziej reprezentatywna grupa społeczna egzystująca w ponowoczesności daje również wyraz istotności czasu teraźniejszego oraz konieczności życia w natychmiastowości współczesnego społeczeństwa. Potwier-

\footnotetext{
${ }^{3}$ Kategoria „ekumena kulturowa” została opisana przez U. Hannerza (2006).
} 
dzają to wyniki badań własnych dotyczących orientacji temporalnej, które wykazały, iż respondenci nie wykazują zainteresowania przeszłością $(70,1 \%)$ oraz są zdania, iż to, co było, minęło i liczy się teraźniejszość, aktualne wydarzenia (81\%) (Peret-Drążewska, 2014: 200). Na podstawie niniejszych danych można wysnuć tezę, iż skoro istotne są teraźniejsze wydarzenia, to kreowana codzienność będzie miała znamiona święta, bowiem nie warto na nie czekać, skoro można je uczcić już dziś. Tak oto codzienność staje się codziennym świętem.

Zatem postrzeganie przez młodzież czasu codziennego i odświętnego, które de facto są zarówno przyczyną, jak i skutkiem owych trendów współczesności, nie pozostaje bez wpływu na preferowany przez młodzież styl życia. Podkreślił to Zbyszko Melosik, pisząc, iż

odwrotowi od Wielkich Idei towarzyszy więc zdecydowana orientacja na życie codzienne. Rytm życia większości młodych ludzi wyznaczony jest przez drobne, codzienne wydarzenia, momenty, czynności (niektórzy autorzy utrzymują, że nasze życie zdominowała „orientacja na sytuacje” bądź wręcz na „epizodyczność”) To one pochłaniają większość psychicznej energii człowieka, stanowiąc cel jego fascynacji i zabiegów. Młodzi ludzie potrafią się delektować drobiazgami, sytuacjami, chwilami, małymi „zatrzymaniami” w życiu. (Melosik, 2013: 159)

Niniejsze nastawienie współczesnych młodych wobec codzienności nie oznacza jednak rezygnacji z ekscytujących doznań i podniosłych przeżyć przynależnych do czasu odświętnego. Istnieje bowiem tendencja do synkretycznego łączenia codzienności $\mathrm{z}$ odświętnością poprzez przeżywanie dnia codziennego w sposób odświętny, co jest de facto wymogiem egzystencj. Zbyszko Melosik konstatuje:

w kulturze współczesnej występuje społecznie skonstruowana obawa (lub wręcz panika) przed monotonnym życiem. Pod wpływem przekazów medialnych młodzi ludzie są przekonani, że ich codziennym obowiązkiem jest nie tylko „natychmiastowa przyjemność”, ale także maksymalizacja wrażeń. Przekaz, który odbierają, głosi bowiem, że nie powinni z niczego rezygnować, że powinni spróbować wszystkiego”. Mają żyć zawsze „na topie" - życie ma być niczym film sensacyjny (albo stanowić fascynujące reality show). (Melosik, 2013: 163)

Interesujących informacji na temat stylu życia w powiązaniu ze specyfiką spędzania czasu, dostarcza przedstawiona przez Zbyszko Melosika koncepcja wszystkożerności, opracowana przez Richarda A. Petersona oraz Rogera M. Kerna (za: Melosik, 2013: 37-38). Zwolennicy wszystkożerności to osoby prowadzące „wewnętrznie zróżnicowany styl życia” składający się zarówno z czynników dostarczanych przez kulturę popularną, jak też wysoką. Są zatem otwarci na wszystkie propozycje kulturowe, nie zamykają się w sztywnych ramach danej 
kultury, ich styl życia stanowi swoistą „hybrydę kulturową” będącą wynikiem indywidualnego, wolnego wyboru. Te typu postawa jest zgodna ze współczesnymi trendami „patchworkowego stylu życia” wolnego od wszystkiego tego, co stałe, jednorodne oraz jasno określone ${ }^{4}$.

\section{Zakończenie i wnioski}

Przedstawione powyżej rozstrzygnięcia na temat czasu codziennego i odświętnego w kontekście specyfiki współczesności oraz okresu młodości nasuwają wniosek, iż mówiąc o stylu życia, należy ujmować go całościowo, bez specyfikacji na styl życia codziennego i styl życia odświętnego.

Pamiętając o fragmentaryzacji i mozaikowatości stylu życia współczesnych młodych oraz o ich nastawieniu wobec czasu, skłaniam się ku tezie mówiącej o spójności stylu życia w kontekście czasu, to znaczy jednym stylu dla codzienności i odświętności, bo skoro oba te wymiary się zlewają w jedno, tak też w jeden styl życia jest to wpisane. Jest to kolejna znamienna cecha współczesności i stylu życia młodych, bowiem niegdyś istniała wyraźna granica i różnica między stylem życia w dniu codziennym i stylem życia w dniu odświętnym.

Po raz kolejny w analizach na temat kondycji współczesnego ponowoczesnego społeczeństwa i stylu życia jednostki, pojawia się wydźwięk słowa-klucza, jakim jest zmiana. Otóż w rzeczywistości permanentnej zmiany zmiana zastanego stanu rzeczy dotyczy również jakości egzystencji jednostki, kreującej swoje życie w przestrzeni codzienności i odświętności, które także zmieniły swój charakter. Tak oto współczesne warunki społeczno-kulturowe bezpośrednio dotykają codziennych spraw ludzkich, które coraz częściej przybierają cechy święta.

Konkludując przedstawione $\mathrm{w}$ artykule analizy, można stwierdzić, że każdy codzienny dzień stał się współcześnie świętem, a co za tym idzie, również święto nabrało wymiaru codzienności. Dotyczy to w szczególności współczesnej młodzieży, która, będąc świadoma specyfiki warunków współczesności, przejmuje je kreując swój styl życia zgodnie z tym, co podpowiadają aktualne trendy społeczno-kulturowe.

\section{Literatura}

Bauman Z. (2009). Niecodzienność nasza codzienna. [W:] M. Bogunia-Borowska (red.). Barwy codzienności. Analiza socjologiczna. Warszawa.

\footnotetext{
${ }^{4}$ Niniejszy fragment tekstu stanowi część artykułu: P. Peret-Drążewska, Styl życia w czasach indywidualizacji. O wolnym wyborze jako kryterium dyferencjacji społecznej, „Studia Edukacyjne” 2014, nr 32, s. 71.
} 
Cybal-Michalska A. (2013). Młodzież akademicka a kariera zawodowa. Kraków.

Hannerz U. (2006). Powiązania transnarodowe: kultura, ludzie, miejsca. Kraków.

Hejwosz-Gromkowska D. (2014). Pedagogika i edukacja wobec kultury natychmiastowości - podsumowanie. [W:] D. Hejwosz-Gromkowska (red.). Rekonstrukcje tożsamości w kulturze natychmiastowości. Poznań.

Jastrzębski J. (2003). Odkrywanie codzienności. [W:] E. Kurantowicz, M. Nowak-Dziemianowicz (red.). Codzienność jako miejsce i źródło uczenia się. „Teraźniejszość - Człowiek - Edukacja. Kwartalnik Myśli Społeczno-Pedagogicznej”, numer specjalny.

Krzychała S. (2007). Projekty życia. Młodzież w perspektywie badań rekonstrukcyjnych. Wrocław.

Melosik Z. (2013). Kultura popularna i tożsamość młodzieży. W niewoli władzy i wolności. Kraków.

Muszyński W. (2009). Syndrom braku czasu we współczesnym społeczeństwie. [W:] W. Muszyński (red.). Nowy wspanialy świat? Moda, konsumpcja i rozrywka jako nowe style życia. Toruń.

Peret-Drążewska P. (2014). Wspótczesna młodzież postrzegana z perspektywy rówieśników. Studium teoretyczno-empiryczne. Poznań.

Sulima R. (2000). Antropologia codzienności. Kraków.

Sztompka P. (2008). Życie codzienne - temat najnowszej socjologii. [W:] P. Sztompka, M. Bogunia-Borowska (red.). Socjologia codzienności. Kraków.

Tarkowska E. (1992). Czas w życiu Polaków. Warszawa. 